\title{
COLD WATER IMMERSION AND INFLAMMATORY RESPONSE AFTER RESISTANCE EXERCISES
}

\author{
IMERSÃO EM ÁGUA FRIA ERESPOSTA INFLAMATÓRIA APÓS EXERCÍCIOS RESISTIDOS
}

INMERSIÓN EN AGUA FRÍA EN RESPUESTA INFLAMATORIA POSTERIOR A EJERCICIOS RESISTIDOS

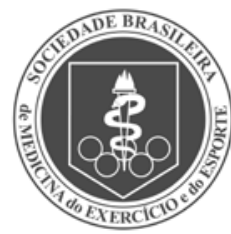

Original Article ARtigo Original Artículo Original
Edson Missau'

(Physiotherapist)

André de Oliveira Teixeira ${ }^{2}$

(Physical Education Professional)

Ozeias Simões Franco ${ }^{2}$ (Physical

Education Professional)

Cassio Noronha Martins²

(Physiotherapist)

Felipe da Silva Paulitsch²

(Physician)

William Peres ${ }^{3}$

(Pharmacist)

Antonio Marcos Vargas da Silva' (Physiotherapist)

Luis Ulisses Signori'

(Physiotherapist)

1. Universidade Federal de Santa Maria (UFSM), Santa Maria, RS, Brazil. 2. Universidade Federal do Rio Grande (FURG), Rio Grande, RS, Brazil.

3. Universidade Federal de Pelotas (UFPel), Pelotas, RS, Brazil.

\section{Correspondence:}

Luis Ulisses Signori.

Physical and Functional

Rehabilitation Graduate Studies Program, Health Sciences Center (CCS), Universidade Federal de Santa Maria - UFSM. Av. Roraima, 1000. Bairro Camobi, Santa Maria, RS, Brazil. 97105-900.

I.signori@hotmail.com

\section{ABSTRACT}

Introduction: High-intensity resistance exercises (RE) cause an inflammatory response that reduces functionality. Objective: To evaluate the effects of Cold Water Immersion (CWI) on leukocytosis, oxidative stress parameters, inflammatory markers and delayed onset muscle soreness (DOMS) resulting from a RE session in untrained volunteers. Methods: Thirteen volunteers (aged $26 \pm 5$ years) who do not engage in RE were randomized and underwent Control RE and RE with CWI sessions. Exercise sessions (leg extension machine, squats and leg presses) consisted of four sets of 10 maximum repetitions (one-week interval between the assessment and the sessions). CWI consisted of immersion in water $\left(15^{\circ} \mathrm{C}\right)$ to the umbilicus for 10 minutes immediately after the exercise session. Complete blood count, CRP, creatine kinase (CK) and lipoperoxidation (LPO) were assessed previously (baseline) and immediately, 30 minutes and 2 hours after RE. DOMS was assessed 24 hours after the sessions. Results: $R E$ induced progressive leukocytosis $(P<0.001)$. CRP was elevated 2 hours after exercise $(P=0.008)$ only in the Control RE session. $C K$ increased 30 minutes and 2 hours after exercise $(P<0.001)$ in the Control session, whereas in the CWI session the increase was observed after 2 hours $(P<0.001)$. LPO increased only in the Control session after 2 hours $(P=0.025)$. CWI reduced DOMS by $57 \%(P<0.001)$. Conclusion: CWI slows the inflammatory response and reduces DOMS in untrained individuals undergoing RE. Level of Evidence l; Randomized Clinical Trial.

Keywords: Exercise; Inflammation; Oxidative stress; Cryotherapy; Clinical trial.

\section{RESUMO}

Introdução: Os exercícios resistidos (ER) de alta intensidade provocam resposta inflamatória que reduz a funcionalidade. Objetivo: Avaliar os efeitos da imersão em água fria (IAF) sobre leucocitose, parâmetros de estresse oxidativo, marcadores inflamatórios e dor muscular de início tardio (DMIT), resultantes de uma sessão ER em voluntários destreinados. Métodos: Treze voluntários (26 \pm 5 anos de idade) não praticantes de ER foram randomizados e submetidos a sessões de ER Controle (ERC) e ER com IAF (ER+IAF). As sessões de exercícios (cadeira extensora, agachamento eleg press) consistiram em quatro séries de 10 repetições máximas (intervalo de uma semana entre a avaliação e as sessões). A IAF consistiu em imersão em água $\left(15^{\circ} \mathrm{C}\right)$, no nível da região umbilical, durante 10 minutos, imediatamente após a sessão de exercícios. Hemograma completo, PCR, creatina quinase (CK) e lipoperoxidação (LPO) foram avaliados previamente (basal) e imediatamente, aos 30 minutos e 2 horas após os ER. A DMIT foi avaliada 24 horas após as sessões. Resultados: Os ER induziram leucocitose progressiva $(P<0,001)$. A $P C R$ foi elevada 2 horas após os exercícios $(P=0,008)$, apenas na sessão de ER Controle. A CK aumentou 30 minutos e 2 horas após os exercícios $(P<0,001)$ na sessão Controle, enquanto na sessão IAF o aumento foi observado após 2 horas $(P<0,001)$. A LPO aumentou somente na ERC depois de 2 horas $(P=0,025)$. A IAF reduziu em 57\% a DMIT ( $P<0,001)$. Conclusão: A IAF retarda a resposta inflamatória e reduz a DMIT em indivíduos destreinados submetidos a ER. Nível de Evidência l; Ensaio Clínico Randomizado.

Descritores: Exercício; Inflamação; Estresse oxidativo; Crioterapia; Ensaio clínico.

\section{RESUMEN}

Introducción: Los ejercicios resistidos (ER) realizados en alta intensidad provocan una respuesta inflamatoria que reduce la funcionalidad. Objetivo: Evaluar los efectos de la inmersión en agua fría (IAF) sobre la leucocitosis, estrés oxidativo, marcadores inflamatorios y en el dolor muscular de inicio tardío (DMIT) resultantes de una sesión de ER en voluntarios no entrenados. Métodos: Trece voluntarios (26 \pm 5 años de edad) no practicantes de ER fueron aleatoriamente sometidos a sesiones de Control ER y ER con IAF. Las sesiones de ejercicios (silla extensora, sentadillas y leg press) consistieron en cuatro series de 10 repeticiones máximas (intervalo de una semana entre la evaluación y las sesiones). La IAF consistió en inmersión en agua $\left(15^{\circ} \mathrm{C}\right)$ a nivel de la cicatriz umbilical, durante 10 minutos posteriores a la sesión de ejercicios. Se realizó un análisis completo de hemograma, $P C R$, creatina quinasa (CK) y lipoperoxidación (LPO), los cuales se evaluaron previa (basal), e inmediatamente después de 30 minutos y 2 horas después de los ER. La DMIT fue evaluada 24 horas después de las sesiones. Resultados: Los ER indujeron a una progresiva leucocitosis $(P<0,001)$. La PCR se elevó 2 horas luego de los ejercicios $(P=0,008)$ apenas 
en la sesión de Control ER. La CK aumentó después de 30 minutos y 2 horas después de los ejercicios $(P<0,001)$ en la sesión Control, mientras que en la sesión IAF el aumento se observó después de 2 horas $(P<0,001)$. La LPO sólo aumentó en la sesión de Control en 2 horas $(P=0,025)$. La IAF redujo en $57 \%$ el DMIT $(P<0,001)$. Conclusión: La IAF retarda la respuesta inflamatoria y reduce la DMIT en individuos no entrenados sometidos a ER. Nivel de Evidencia I, Ensayo Clínico Randomizado.

Descriptores: Ejercicio; Inflamación; Estrés Oxidativo; Crioterapia; Ensayo Clínico.

\section{INTRODUCTION}

Resistance exercise (RE) is used to develop skeletal muscle hypertrophy and/or strength. REs should be part of all exercise programs, as they contribute to improvement of sports performance and prophylaxis and treatment of disease. ${ }^{1}$ REs acutely generate mechanical and/or metabolic stress that may vary according to training variables and may result in muscle damage, depending on intensity. ${ }^{2}$

Oxidation/reduction imbalance ${ }^{3}$ occurs during and after REs in high-intensity sessions because the production of reactive oxygen species (ROS) exceeds enzymatic (superoxide dismutase, catalase, and glutathione peroxidase) and nonenzymatic (vitamins $A, C$, and $E$, and uric acid) antioxidant capacity, resulting in oxidation of cellular constituents ${ }^{4,5,6}$ and an inflammatory response. . $^{3,7}$ These alterations are clinically characterized by delayed-onset muscle soreness (DOMS), which results in reduced contractility ${ }^{8}$ and muscular functionality. ${ }^{9}$ Sedentary and/ or untrained individuals are especially vulnerable, 2,9 because DOMS is a transient condition (peak at 24-72 h and symptom resolution in 5-7 days $)^{10}$ that may lead to exercise program dropout., ${ }^{2,9}$

A variety of therapeutic strategies are being investigated to minimize and/or accelerate DOMS recovery. ${ }^{9,11,12}$ One of these strategies is cold water immersion (CWI). Many studies have shown that CWI is favorable for recovery from DOMS and improves muscle function after exercise. 6,10,13-25 CWI acutely promotes recovery from central fatigue, improves blood flow distribution (redirection of blood flow from peripheral to central areas), improves metabolic clearance, and reduces sympathetic activity. ${ }^{26}$ However, these effects vary according to exercise type, individual characteristics, and CWI protocol (time of application, temperature, and body area immersed). ${ }^{27}$

A recent meta-analysis suggested that the optimal protocol for use of CWI included water temperature of $11-15^{\circ} \mathrm{C}$ and application for 11-15 min. ${ }^{21}$ However, the mechanisms involved are still not fully understood ${ }^{6,27}$; moreover, as the redox status following RE in untrained individuals has not been studied, this recommended protocol should be reconsidered. ${ }^{25}$ This study aimed to understand acute changes in hematological dynamics, inflammatory markers, oxidative stress parameters, and DOMS in healthy, untrained volunteers treated with $\mathrm{CWI}\left(15^{\circ} \mathrm{C}\right.$ for 10 min) after an acute RE session.

\section{METHOD}

The present randomized, single-arm, single-blind crossover trial was approved by the Research Ethics Committee (CEPAS/FURG protocol no. 23116.002536/2010-48) and registered at ClinicalTrials.gov (Identifier: NCT02902315). All participants gave signed informed consent.

\section{Eligibility criteria}

The volunteers in the study were clinically healthy, aged 20-35 years, with a body mass index (BMI) $<30 \mathrm{~kg} / \mathrm{m}^{2}$, and did not practice physical activity and/or exercise regularly (+1 time per week) or participate in diet programs, and had no previous diagnosis of rheumatological, cardiovascular, metabolic, neurological, oncological, immunological, or hematological diseases. Smokers and individuals who used any type of food, vitamin, and/or ergogenic supplement or medication were not included in the study.

Exclusion criteria were the presence during the study of musculoskeletal lesions; use of anti-inflammatory and/or analgesic medications; and any baseline laboratory test showing an inflammatory response (C-reactive protein [CRP] $>3 \mathrm{mg} / \mathrm{dL}$ ), leukocytosis $\left(>11,000 \times 10^{3} / \mathrm{mm}^{3}\right)$, hyperthermia $\left(>38^{\circ} \mathrm{C}\right)$, changes in systemic arterial pressure $(>140 / 90$ $\mathrm{mmHg}$ ); and any symptoms of pain and/or discomfort prior to baseline evaluation. The study flow chart is presented in Figure 1. The consumption of fruit juices and alcoholic beverages, as well as physical activities, were restricted for $72 \mathrm{~h}$ prior to data collection.

\section{Assessment of muscle strength}

The 10-repetition maximum test (10RM) was used in the training protocol with controlled overload. ' The selected exercises (extensor chair, squat, and leg press) were performed using Physicus ${ }^{\circ}$ equipment (model Plus, Brazil). During data collection, a 5-min recovery time was allowed between exercises. The maximum load values in the 10RM test were obtained after 3 to 5 attempts, when the volunteer showed consistent failure of dynamic movement. Each new attempt was followed by a progressive increment of $5 \mathrm{~kg}$, and the maximum load in the last attempt was used for analysis. A range of 3 to 4 min was used between each series. ${ }^{7,28}$

\section{Exercise session}

Before the exercise session, volunteers performed a warm-up specific for each exercise (a series of 15 repetitions with $40 \%$ of maximum load). Exercise sessions were composed of 4 series at 10RM, with intervals of 1 min between series and 2 min between exercises. Prior to 10RM testing and data collection, the participants received standardized instructions about the experimental procedure and exercise technique. Volunteers were verbally encouraged during assessment and exercise. ${ }^{7,28}$

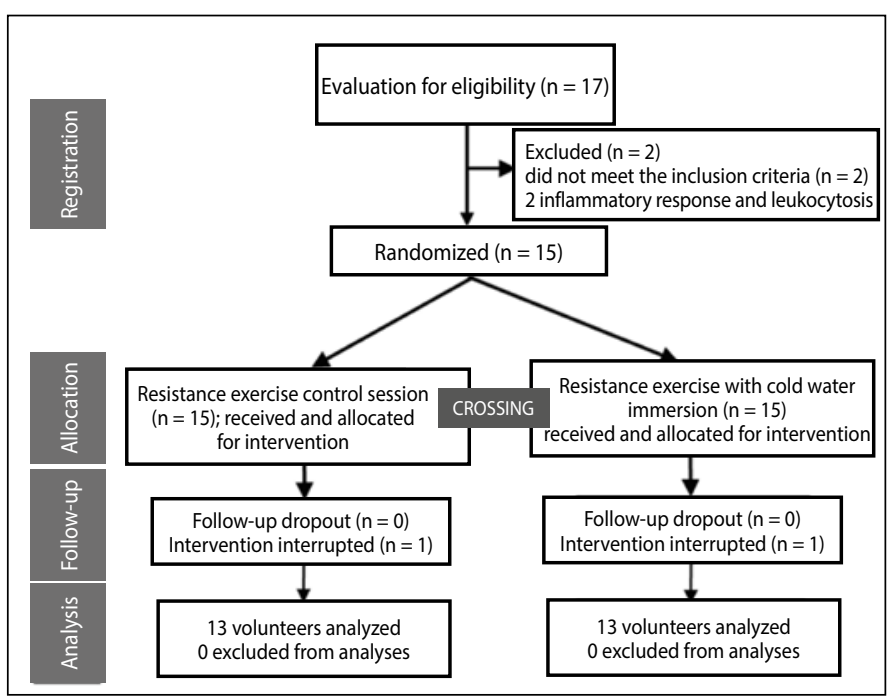

Figure 1. Creating the samples. 


\section{Intervention}

The RE session (RES) included CWI of the lower limbs at $15^{\circ} \mathrm{C}$ for 10 min immediately after exercise. ${ }^{21}$ The volunteer was seated and the water level reached the umbilicus. The RE control session (RECS) followed the same protocol, but without CWI. The exercise sequence (extensor chair, squat, and leg press), RECS, and RES + CWI were randomized using a software program (www.random.org).

\section{Data collection and biochemical measurements}

The volunteers fasted for $12 \mathrm{~h}$ on the day of data collection. Blood samples were collected before (baseline), immediately after ( 0 min), and 30 and 120 min after the RE session. DOMS was assessed $24 \mathrm{~h}$ after the exercise session using a visual analog scale.?

Total cholesterol, triglycerides, high-density lipoprotein cholesterol (HDLC), glucose, uric acid, urea, and fibrinogen were evaluated using commercial test kits (Lagoa Santa, MG, Brazil). Low-density lipoprotein cholesterol (LDLC) was determined using the Friedewald formula. The Biuret colorimetric method (Doles, GO, Brazil) was used to measure total plasma proteins. Lactate was evaluated using test strips (Roche Diagnostics GmbH, Mannheim, Germany). Creatine kinase (CK) was measured using the CK-NAC Liquiform device (Mindray, model BS200, China). Ultrasensitive CRP was measured with nephelometry (Beckman Coulter, Fullerton, CA, USA). Erythrograms and leukograms were automatically processed (ABX kits, Horiba Diagnóstica, Curitiba, Brazil) and analyzed with microscopy. All samples were measured twice and values were expressed as the mean of measurements (differences $>10 \%$ were repeated).

Plasma lipoperoxidation (LPO) was measured though $\mathrm{Fe}^{2+}$ oxidation using lipid hydroperoxide in acid medium and in the presence of an $\mathrm{Fe}^{3+}$ complex (Xylenol Orange dye; SIGMA, SP, Brazil). A microplate reader (550-nm wavelength) was used in the analysis. Cumene hydroperoxide (SIGMA, SP, Brazil) was used as a standard. Results are expressed as nmol of cumene hydroperoxide/g of protein.?

Total antioxidant capacity against peroxyl radicals $\left(\mathrm{RO}_{2} \cdot\right.$ ) (ACAP) was analyzed using $10 \mu \mathrm{L}$ of plasma diluted to a concentration of $3.3 \mathrm{mg} /$ $\mathrm{mL}$ protein and pipetted into 8 bottom-well white microplates. Then, $127.5 \mathrm{LL}$ of the reaction buffer (30 mM HEPES, pH 7.2; $200 \mathrm{mM} \mathrm{KCl} ; 1 \mathrm{mM}$ $\mathrm{MgCl}_{2}$ ) was added to the wells with the samples. Four wells per sample received $7.5 \mu \mathrm{L}$ of 2,20-azobis (2-methylpropionamidine) dihydrochloride (ABAP; 4mM; Sigma-Aldrich, SP, Brazil) and 4 wells per sample received $7.5 \mu \mathrm{L}$ of ultrapure water. Baseline fluorescence was measured using a fluorometer (Victor 2, Perkin-Elmer, Turku, Finland) at $35^{\circ} \mathrm{C}$, where peroxyl radicals are produced from ABAP thermolysis. After determining the baseline fluorescence, $10 \mu \mathrm{L}$ of 20,70-dichlorofluorescein-diacetate (H2DCF-DA) was added to the wells, resulting in a final concentration of $40 \mu \mathrm{M}$. Fluorescence generation was monitored every $5 \mathrm{~min}$ for $1 \mathrm{~h}$. The data are expressed as 1/(relative area with/without ABAP)?

\section{Statistical analyses}

Sample calculation was based on a previous study, ${ }^{23}$ and yielded an estimated need for 13 volunteers. After applying CWI, we estimated a difference of 1.4 points (visual analog scale) between sessions and a standard deviation of 1.6 points. These values were maintained for a power of $80 \%$ and $a=0.05$.

The data are expressed as mean $(X) \pm$ standard deviation (SD). The Kolmogorov-Smirnov test was used to verify data distribution. A paired Student's t-test was used to compare variables with 2 measurements, and variables with more than 2 measurements were assessed with 2-way repeated measures ANOVA, followed by the Bonferroni post hoc test. The level of significance was considered $5 \%(p<0.05)$.

\section{RESULTS}

The sample included 13 healthy, sedentary volunteers with a mean age of $26.6 \pm 5$ years, with similar characteristics across sessions, as follows: BMI (RECS $25.8 \pm 3 \mathrm{~kg} / \mathrm{m}^{2}$ vs. RES + CWI $25.6 \pm 3 \mathrm{~kg} / \mathrm{m}^{2}, p=0.173$ ), systolic blood pressure (RECS $116 \pm 6 \mathrm{mmHg}$ vs. RES + CWI $120 \pm 5 \mathrm{mmHg}$, $p=0.178$ ), and diastolic blood pressure (RECS $75 \pm 4 \mathrm{mmHg}$ vs. RES +CWI $78 \pm 5 \mathrm{mmHg}, \mathrm{p}=0.672$ ). Lipid profile, glucose, uric acid, and urea values were within the recommended range for the age group and did not change between sessions (Table 1). Lactate increased approximately 7-fold from baseline during RE sessions (Figure 2A).

The erythrogram and leukogram results were within normal limits and are shown in Tables 2 and 3, respectively. Immediately after RE, there was an increase in hematocrit, red blood cell count, and hemoglobin, and these returned to basal levels at 30 and 120 min. Platelets increased with RE at 0 min, and decreased at 30 and $120 \mathrm{~min}$, but did not return to baseline values.

Total leukocytes and segmented neutrophils increased immediately after an RE session, returning to baseline values 30 min after the end of the session and increasing again at $120 \mathrm{~min}$ in both sessions. Bands increased at 120 min after the end of both exercise sessions, but the values were only higher than those immediately after the end of RE in the RECS. In both sessions, monocytes increased immediately after RE, returning to baseline values in the other evaluations. Lymphocytes increased immediately after RE (0 min) during the CWI session and decreased to baseline values at 30 min, but this only occurred after 120 min in the RECS.

The data on oxidative stress parameters and inflammatory markers are shown in Table 4. LPO increased $120 \mathrm{~min}$ after the end of the exercises only in the RECS (Figure 2B). ACAP did not change throughout the study. CRP increased at 120 min compared to baseline values only in the RECS. CK increased above baseline values at 30 and 120 min after the end of control exercises, but this increase was only observed at 120 min after the end of RE + CWI. Fibrinogen did not change throughout the study. DOMS assessed $24 \mathrm{~h}$ after exercise sessions showed a 57\% reduction following RE + CWI (Figure 2C).

\section{DISCUSSION}

The results of the present study show that CWI decreased leukocytosis and lipoperoxidation, attenuated increased inflammatory markers (CRP and CK), and decreased DOMS $24 \mathrm{~h}$ after the RE session in healthy, untrained volunteers. Leukocytosis after RE occurs due to an inflammatory response ${ }^{7}$ and hemoconcentration. ${ }^{28}$ Hemoconcentration primarily occurs in the first 30 min after RE, and is responsible for an increase in erythrocytes and platelets, as demonstrated in previous studies. ${ }^{7,28} \mathrm{CWI}$ delayed the increase in immature neutrophils and platelets, suggesting this intervention interferes in the recruitment of these cells.,22

Cell signaling occurs through the redox state and during intense exercise can result in damage to cell constituents. ${ }^{4,5,6,25}$ The present study showed that $\mathrm{CWI}$ reduced lipid damage at 120 min after RE. To our knowledge,

Table 1. Clinical and metabolic characteristics of volunteers in different resistance exercise sessions.

\begin{tabular}{c|c|c|c}
\hline Variables & $\begin{array}{c}\text { RECS } \\
(\mathbf{X} \pm \mathbf{S D})\end{array}$ & $\begin{array}{c}\text { RES+CWI } \\
(\mathbf{X} \pm \mathbf{S D})\end{array}$ & p value \\
\hline Total cholesterol $(\mathrm{mg} / \mathrm{dL})$ & $150.4 \pm 30$ & $149.1 \pm 33$ & 0.942 \\
\hline Triglycerides $(\mathrm{mg} / \mathrm{dL})$ & $103.6 \pm 49$ & $89.3 \pm 38$ & 0.320 \\
\hline HDLc $(\mathrm{mg} / \mathrm{dL})$ & $33.5 \pm 6$ & $34.3 \pm 7$ & 0.587 \\
\hline LDLc $(\mathrm{mg} / \mathrm{dL})$ & $94.2 \pm 27$ & $93.9 \pm 25$ & 0.966 \\
\hline Glucose $(\mathrm{mg} / \mathrm{dL})$ & $88.8 \pm 8$ & $87.3 \pm 12$ & 0.624 \\
\hline Uric Acid $(\mathrm{mg} / \mathrm{dL})$ & $5.1 \pm 0.7$ & $5.1 \pm 0.5$ & 0.781 \\
\hline Urea $(\mathrm{mg} / \mathrm{dL})$ & $30.4 \pm 7$ & $29.8 \pm 8$ & 0.543 \\
\hline
\end{tabular}

Resistance Exercise Control Session; RES+CWI: Resistance Exercise Session with Cold Water Immersion; HDLC High-density lipoprotein cholesterol, LDLc: Low-density lipoprotein cholesterol. 
Table 2. Erythrogram changes after resistance exercise sessions.

\begin{tabular}{|c|c|c|c|c|c|c|c|c|}
\hline \multirow{3}{*}{ Variables } & \multirow{3}{*}{ Session } & \multicolumn{4}{|c|}{ Blood collections } & \multicolumn{3}{|c|}{ p value } \\
\hline & & Baseline & $0 \mathrm{~min}$ & $30 \mathrm{~min}$ & $120 \mathrm{~min}$ & \multirow{2}{*}{ Sessions } & \multirow[b]{2}{*}{ Time } & \multirow{2}{*}{ Interaction } \\
\hline & & $(X \pm S D)$ & $(X \pm S D)$ & $(X \pm S D)$ & $(X \pm S D)$ & & & \\
\hline \multirow{2}{*}{ Hematocrit $\left(m L \%^{-1}\right)$} & RECS & $47.0 \pm 2.5$ & $49.1 \pm 2.9^{*}$ & $46.8 \pm 3.0^{+}$ & $46.4 \pm 3.0^{\dagger}$ & \multirow{2}{*}{0.727} & \multirow{2}{*}{$<0.001$} & \multirow{2}{*}{0.368} \\
\hline & RES+CWI & $47.1 \pm 2.0$ & $49.0 \pm 3.0^{*}$ & $47.3 \pm 2.6^{+}$ & $47.3 \pm 2.3^{\dagger}$ & & & \\
\hline \multirow{2}{*}{ Erythrocytes $\left(\times 10^{5} / \mathrm{mm}^{3}\right)$} & RECS & $5.1 \pm 0.3$ & $5.4 \pm 0.4^{*}$ & $5.1 \pm 0.3^{\dagger}$ & $5.1 \pm 0.4^{\dagger}$ & \multirow{2}{*}{0.715} & \multirow{2}{*}{$<0.001$} & \multirow{2}{*}{0.273} \\
\hline & RES+CWI & $5.2 \pm 0.2$ & $5.3 \pm 0.3^{*}$ & $5.2 \pm 0.3^{\dagger}$ & $5.2 \pm 0.3^{\dagger}$ & & & \\
\hline \multirow{2}{*}{ Hemoglobin (g/dL) } & RECS & $15.4 \pm 0.9$ & $16.1 \pm 1.1^{*}$ & $15.4 \pm 1.1^{\dagger}$ & $15.3 \pm 1.0^{\dagger}$ & \multirow{2}{*}{0.553} & \multirow{2}{*}{$<0.001$} & \multirow{2}{*}{0.241} \\
\hline & $\mathrm{CS}+\mathrm{CWI}$ & $15.5 \pm 0.6$ & $16.1 \pm 0.9^{*}$ & $15.7 \pm 0.9^{\dagger}$ & $15.6 \pm 0.9^{\dagger}$ & & & \\
\hline \multirow{2}{*}{ Platelets $\left(\times 10^{3 /} \mathrm{mm}^{3}\right)$} & RECS & $228 \pm 40$ & $270 \pm 56^{*}$ & $239 \pm 43^{* \dagger}$ & $244 \pm 42^{*+}$ & \multirow{2}{*}{0.993} & \multirow{2}{*}{$<0.001$} & \multirow{2}{*}{0.825} \\
\hline & RES+CWI & $224 \pm 35$ & $272 \pm 40^{*}$ & $243 \pm 37^{\dagger}$ & $242 \pm 37^{*+}$ & & & \\
\hline
\end{tabular}

RECS: Resistance Exercise Control Session, RES+CWI: Resistance Exercise Session with Cold Water Immersion; ${ }^{*} \mathrm{p}<0.05$ vs. baseline; ${ }^{\dagger} \mathrm{p}<0.05$ vs. 0 min.

Table 3. Leukogram changes after resistance exercise sessions.

\begin{tabular}{|c|c|c|c|c|c|c|c|c|}
\hline \multirow{3}{*}{ Variables } & \multirow{3}{*}{ Session } & \multicolumn{4}{|c|}{ Blood collections } & \multicolumn{3}{|c|}{$p$ value } \\
\hline & & Baseline & $0 \mathrm{~min}$ & $30 \mathrm{~min}$ & $120 \mathrm{~min}$ & \multirow{2}{*}{ Sessions } & \multirow{2}{*}{ Time } & \multirow{2}{*}{ Interaction } \\
\hline & & $(\mathrm{X} \pm \mathrm{SD})$ & $(\mathrm{X} \pm \mathrm{SD})$ & $(\mathrm{X} \pm \mathrm{SD})$ & $(\mathrm{X} \pm \mathrm{SD})$ & & & \\
\hline \multirow{2}{*}{ Total leukocytes $\left(\times 10^{3} / \mathrm{mm}^{3}\right)$} & RECS & $6854 \pm 1005$ & $8300 \pm 1398^{*}$ & $6569 \pm 881$ & $8092 \pm 1773^{*+\neq}$ & \multirow{2}{*}{0.587} & \multirow{2}{*}{$<0.001$} & \multirow{2}{*}{0.930} \\
\hline & RES+CWI & $7056 \pm 1449$ & $8433 \pm 1577^{*}$ & $6833 \pm 1306$ & $8538 \pm 1823^{*+\neq}$ & & & \\
\hline \multirow{2}{*}{$\begin{array}{l}\text { Segmented neutrophils }\left(\times 10^{3} /\right. \\
\left.\qquad \mathrm{mm}^{3}\right)\end{array}$} & RECS & $3710 \pm 820$ & $4690 \pm 1062^{*}$ & $3916 \pm 757^{+}$ & $5116 \pm 1808^{*+\neq}$ & \multirow{2}{*}{0.394} & \multirow{2}{*}{$<0.001$} & \multirow{2}{*}{0.721} \\
\hline & RES+CWI & $4081 \pm 1162$ & $4911 \pm 1309^{*}$ & $4224 \pm 1248^{\dagger}$ & $5745 \pm 1580^{* * \neq}$ & & & \\
\hline \multirow{2}{*}{ Young neutrophils $\left(\times 10^{3} / \mathrm{mm}^{3}\right)$} & RECS & $73 \pm 15$ & $84 \pm 15$ & $66 \pm 9$ & $128 \pm 112^{* \neq \neq}$ & \multirow{2}{*}{0.696} & \multirow{2}{*}{$<0.001$} & \multirow{2}{*}{0.878} \\
\hline & RES+CWI & $76 \pm 21$ & $97 \pm 29$ & $73 \pm 15$ & $121 \pm 63^{* \neq}$ & & & \\
\hline \multirow{2}{*}{ Eosinophils $\left(\times 10^{3} / \mathrm{mm}^{3}\right)$} & RECS & $118 \pm 75$ & $102 \pm 42$ & $86 \pm 36$ & $121 \pm 84$ & \multirow{2}{*}{0.074} & \multirow{2}{*}{0.052} & \multirow{2}{*}{0.766} \\
\hline & RES+CWI & $178 \pm 90$ & $164 \pm 114$ & $149 \pm 94$ & $162 \pm 107$ & & & \\
\hline \multirow{2}{*}{ Monocytes $\left(\times 10^{3} / \mathrm{mm}^{3}\right)$} & RECS & $297 \pm 95$ & $429 \pm 103^{*}$ & $284 \pm 70^{+}$ & $302 \pm 104^{+}$ & \multirow{2}{*}{0.862} & \multirow{2}{*}{$<0.001$} & \multirow{2}{*}{0.864} \\
\hline & RES+CWI & $312 \pm 71$ & $415 \pm 93^{*}$ & $282 \pm 72^{\dagger}$ & $319 \pm 75^{\dagger}$ & & & \\
\hline \multirow{2}{*}{ Lymphocytes $\left(\times 10^{3} / \mathrm{mm}^{3}\right)$} & RECS & $2589 \pm 502$ & $2989 \pm 753^{*}$ & $2216 \pm 525^{*+}$ & $2471 \pm 494^{\dagger}$ & \multirow{2}{*}{0.662} & \multirow{2}{*}{$<0.001$} & \multirow{2}{*}{0.581} \\
\hline & RES+CWI & $2440 \pm 490$ & $3040 \pm 837^{*}$ & $2190 \pm 357^{\dagger}$ & $2265 \pm 444^{+}$ & & & \\
\hline
\end{tabular}

Resistance Exercise Control Sessions; RES+CWl: Resistance Exercise Session with Cold Water Immersion. ${ }^{*} p<0.05$ vs. baseline; ${ }^{\dagger} p<0.05$ vs. 0 min; ${ }^{*} p<0.05$ vs. 30 min.

Table 4. Changes in inflammatory markers and oxidative stress parameters after resistance exercise sessions.

\begin{tabular}{|c|c|c|c|c|c|c|c|c|}
\hline \multirow[b]{2}{*}{ Variables } & \multirow[b]{2}{*}{ Session } & \multicolumn{4}{|c|}{ Blood collections } & \multicolumn{3}{|c|}{ p value } \\
\hline & & $\begin{array}{l}\text { Baseline } \\
(\mathrm{X} \pm \mathrm{SD})\end{array}$ & $\begin{array}{c}0 \min \\
(X \pm S D)\end{array}$ & $\begin{array}{c}30 \mathrm{~min} \\
(\mathrm{X} \pm \mathrm{SD})\end{array}$ & $\begin{array}{l}120 \min \\
(X \pm S D)\end{array}$ & Sessions & Time & Interaction \\
\hline \multirow{2}{*}{$\mathrm{CRP}(\mathrm{mg} / \mathrm{dL})$} & RECS & $0.90 \pm 0.7$ & $1.13 \pm 1.0$ & $1.15 \pm 1.1$ & $1.32 \pm 1.3^{*}$ & \multirow{2}{*}{0.898} & \multirow{2}{*}{0.008} & \multirow{2}{*}{0.430} \\
\hline & RES+CWI & $1.01 \pm 0.9$ & $1.27 \pm 1.43$ & $1.25 \pm 1.7$ & $1.19 \pm 1.2$ & & & \\
\hline \multirow{2}{*}{ Creatine Kinase $(U / L)$} & RECS & $174 \pm 66$ & $187 \pm 62$ & $199 \pm 77^{*}$ & $222 \pm 93^{*+}$ & \multirow{2}{*}{0.396} & \multirow{2}{*}{$<0.001$} & \multirow{2}{*}{0.871} \\
\hline & RES+CWI & $155 \pm 56$ & $164 \pm 67$ & $169 \pm 76$ & $195 \pm 100^{* \neq \neq}$ & & & \\
\hline \multirow{2}{*}{ Fibrinogen (mg/dL) } & RECS & $280 \pm 89$ & $271 \pm 103$ & $283 \pm 84$ & $287 \pm 101$ & \multirow{2}{*}{0.631} & \multirow{2}{*}{0.513} & \multirow{2}{*}{0.591} \\
\hline & RES+CWI & $271 \pm 61$ & $295 \pm 35$ & $306 \pm 41$ & $295 \pm 30$ & & & \\
\hline \multirow{2}{*}{ LPO (nmol CHP/ $\mu \mathrm{L})$} & RECS & $8.8 \pm 4$ & $11.8 \pm 6$ & $11.2 \pm 6$ & $15.6 \pm 11^{*}$ & \multirow{2}{*}{0.854} & \multirow{2}{*}{0.025} & \multirow{2}{*}{0.069} \\
\hline & RES+CWI & $10.2 \pm 5$ & $13.2 \pm 9$ & $11.2 \pm 6$ & $11.0 \pm 6$ & & & \\
\hline \multirow{2}{*}{$\begin{array}{c}\text { ACAP } \\
(1 / \text { relative area with/without ABAP }))\end{array}$} & RECS & $0.043 \pm 0.04$ & $0.039 \pm 0.03$ & $0.040 \pm 0.034$ & $0.038 \pm 0.03$ & \multirow{2}{*}{0.834} & \multirow{2}{*}{0.451} & \multirow{2}{*}{0.414} \\
\hline & RES+CWI & $0.042 \pm 0.03$ & $0.039 \pm 0.02$ & $0.047 \pm 0.03$ & $0.045 \pm 0.03$ & & & \\
\hline
\end{tabular}

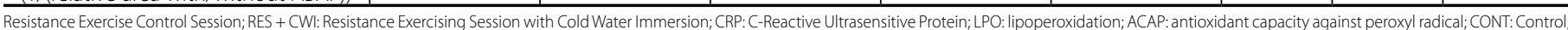
CWl: Cold Water Immersion. ${ }^{*} p<0.05$ vs. baseline; ${ }^{+} p<0.05$ vs. Omin; ${ }^{*} p<0.05$ vs. $30 \mathrm{~min}$.
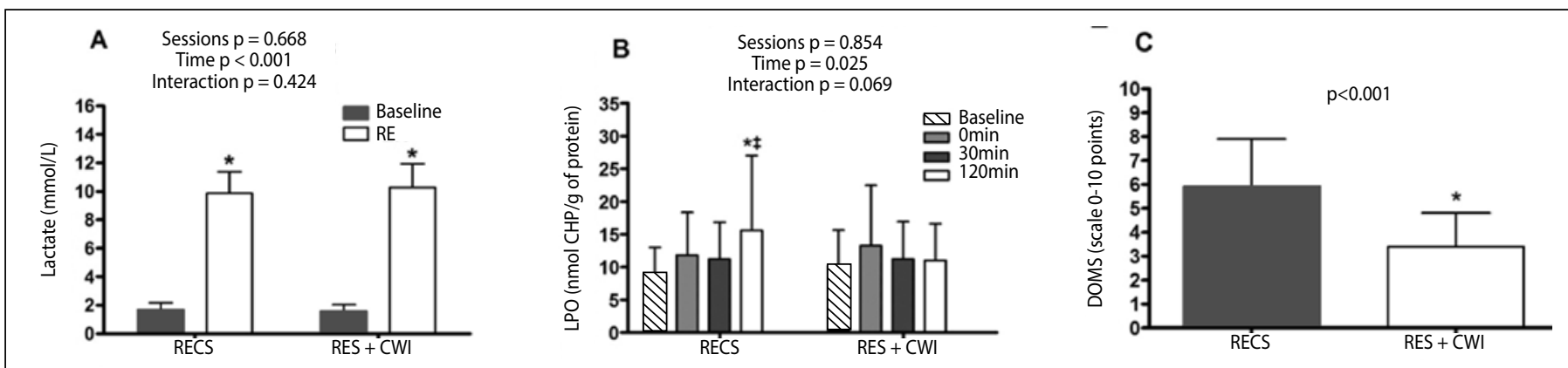

CWI: Cold Water Immersion. ${ }^{*} p<0.05$ vs. Baseline or Control Session; $\uparrow p<0.05$ vs. 0 min; $\neq p<0.05$ vs. 30 min.

Figure 2. Lactate changes after resistance exercise sessions. 2B. Lipoperoxidation changes after resistance exercise sessions. 2C. Delayed Onset Muscle Pain (DOMS) evaluated $24 \mathrm{~h}$ after resistance exercise sessions.

this is the first meta-analysis ${ }^{21}$ showing that CWI using recommended parameters (11-15० $\mathrm{C}$ and 11-15 $\mathrm{min}$ ) reduced damage caused by transient oxidative stress in untrained volunteers following RE sessions. CWI $\left(3^{\circ} \mathrm{C}\right.$ for $5 \mathrm{~min}$ ) applied after an exercise session using a cycle ergometer reduced lipoperoxidation and damage caused by redox imbalance. ${ }^{4}$ A study on volleyball players exposed to cold air ( $-130^{\circ} \mathrm{C}$ for $2 \mathrm{~min}$ ) before submaximal exercise using a cycle ergometer corroborated this result, as shown by improved enzymatic antioxidant capacity and reduced inflammatory markers. ${ }^{5}$ Semi-professional mixed martial arts athletes who underwent
CWI (10 $\mathrm{C}$ for $15 \mathrm{~min})$ had reduced oxidative damage. ${ }^{13}$ In physically-active young individuals, $\mathrm{CWI}\left(10^{\circ} \mathrm{C}\right.$ for $\left.10 \mathrm{~min}\right)$ after RE reduced the infiltration of neutrophils and monocytes and the production of inflammatory markers, as demonstrated in muscle biopsies. ${ }^{22}$

In the present study, CWI delayed the increase in CRP and CK in blood after RE sessions. CRP and CK are biomarkers of systemic inflammation and muscle damage, ${ }^{29}$ respectively, and CK increases are due to sarcolemma lesions. ${ }^{30}$ These CK results agree with previous studies. ${ }^{14,20,23}$ However, Bleakley et al. ${ }^{29}$ did not find differences between CWI and 
passive recovery in plasma levels of these biomarkers. We believe this difference is due to different exercise protocols, and especially to different CWI parameters. ${ }^{27}$ The parameters used in this study were described in recent studies ${ }^{13,20,21,23}$ that provided better clinical evidence.

The effects of CWI on DOMS reduction demonstrated in this research have been described in a systematic review of different types of exercise ${ }^{29}$ in healthy adults ${ }^{20}$ and martial arts practitioners. ${ }^{13}$ It is important to stress that there is high interindividual variability in the DOMS response (13$22 \%)$, which should be considered of clinical relevance. ${ }^{29}$ The results of the present study show a 57\% reduction in DOMS, which demonstrates the effectiveness of this intervention.

This research indicates that $C W I$ reduces pain perception partly due to reduced nerve conduction velocity and reduced muscle and central fati$g^{26}{ }^{26}$. In addition, changes in muscle blood flow favor metabolite remova ${ }^{26}$, and also reduce $\mathrm{ROS}^{6,26,27}$ formation and oxidative damage $\mathrm{e}^{5,13}$ associated with decreased temperature and metabolism, as demonstrated in the present study by the reduction of lipoperoxidation. These mechanisms decrease inflammatory signaling and edema, and attenuate secondary injury to muscle fibers, ${ }^{27}$ as demonstrated in this study by decreased CK,
CRP, and leukocytosis. On the other hand, CWI after exercise can decrease adaptive processes and performance resulting from physical training. 25,27

\section{CONCLUSIONS}

The present study showed that CWI as recommended (upper temperature limit $15^{\circ} \mathrm{C}$ and lower time limit $10 \mathrm{~min}$ ) favors redox balance, attenuates leukocytosis and the inflammatory response, and reduces DOMS, thereby promoting adaptation of beginners to RE training. However, this intervention may also affect adaptive musculoskeletal processes resulting from $\mathrm{RE}$, and its application in training programs should be further investigated.

\section{ACKNOWLEDGMENTS}

We thank the National Council for Scientific and Technological Development (CNPq) and the Research Support Foundation of the State of Rio Grande do Sul (FAPERGS) for the support.

All authors declare no potential conflict of interest related to this article.

AUTHORS' CONTRIBUTIONS: Each author made significant individual contributions to this manuscript. AOT (0000-0003-3202-6179)*, OSF (0000-0002-3108-6543)*, CNM (0000-00022344-6844)* and WP (0000-0001-6313-2519)* contributed to the recruitment of volunteers, fact finding and data analyses. EM (0000-0002-1759-3063)*, AMVS (0000-0001-8127-6911)* carried out data interpretation and the writing of the manuscript. FSP (0000-0003-0319-2194)* and LUS (0000-0001-7784-9940)* are responsible for the creation of the project, carried out the statistical analyses, and performed a critical review. All the authors contributed to the revision of the manuscript. *ORCID (Open Researcher and Contributor ID).

\section{REFERENCES}

1. American College Sports Medicine. American College of Sports Medicine. Progression Models in resistance training for healthy adults. Med Sci. Sport Exerc. 2009;41(3):687-708.

2. Paulsen G, Mikkelsen UR, RaastadT, Peake JM. Leucocytes, cytokines and satellite cells: what role do they play in muscle damage and regeneration following eccentric exercise? Exerc Immunol Rev. 2012;18:42-97.

3. Bessa AL, Oliveira VN, Agostini GG, Oliveira RJ, Oliveira AC, White GE, et al. Exercise intensity and recovery: biomarkers of injury, inflammation, and oxidative stress. J Strength Cond Res. 2016;30(2):311-9.

4. Sutkowy P, Woźniak A, Boraczyński T, Mila-Kierzenkowska C, Boraczyński M. Postexercise impact of ice-cold water bath on the oxidant-antioxidant balance in healthy men. Biomed Res Int. 2015;2015:1-8.

5. Mila-Kierzenkowska C, Jurecka A, Woźniak A, Szpinda M, Augustyńska B, Woźniak B. The effect of submaximal exercise preceded by single whole-body cryotherapy on the markers of oxidative stress and inflammation in blood of volleyball players. Oxidative Medicine Cell Longev. 2013;2013:1-10.

6. Bleakley CM, Davison GW. What is the biochemical and physiological rationale for using cold-water immersion in sports recovery? A systematic review. Br J Sports Med. 2010;44(3):179-87.

7. Teixeira ADO, Paulitsch FS, Umpierre MM, Moraes MB, Rosa CE, Signori LU. Inflammatory response after session of resistance exercises in untrained volunteers. Acta Sci Heal Sci. 2014;37(1):31-9.

8. Ibrahim MY, Ashour OM. Changes in nitric oxide and free radical levels in rat gastrocnemius muscle during contraction and fatigue. Clin Exp Pharmacol Physiol. 2011;38(12):791-5.

9. Cheung K, Hume PA, Maxwell L. Treatment strategies and performance factors. Sports Med. 2003;33(2):145-64.

10. Glasgow PD, Ferris R, Bleakley CM. Cold water immersion in the management of delayed-onset muscle soreness: Is dose important? A randomised controlled trial. Phys Ther Sport. 2014;15(4):228-33.

11. Howatson G, Hoad M, Goodall S, Tallent J, Bell PG. French, Duncan N. Exercise-induced muscle damage is reduced in resistance-trained males by branched chain amino acids: a randomized, double-blind, placebo controlled study. J Int Soc Sports Nutr. 2012;9(20):1-7.

12. Minett GM, Duffield R. Is recovery driven by central or peripheral factors? A role for the brain in recovery following intermittent-sprint exercise. Front Physiol. 2014;5:24.

13. Lindsay A, Carr S, Cross S, Petersen C, Lewis JG, Gieseg SP. The physiological response to cold water immersion following a mixed martial arts training session. Appl Physiol Nutr Metab. 2017;42(5):529-36.

14. Higgins TR, Greene DA, Baker MK. Effects of cold water immersion and contrast water therapy for recovery from team sport: a systematic review and meta-analysis. J Strength Cond Res. 2017;31(5):1443-50.

15. Stanley J, Buchheit M, Peake JM. The effect of post-exercise hydrotherapy on subsequent exercise performance and heart rate variability. Eur J Appl Physiol. 2012;112(3):951-61.

16. Roberts LA, Muthalib M, Stanley J, Lichtwark G, Nosaka K, Coombes JS, et al. Effects of cold water immersion and active recovery on hemodynamics and recovery of muscle strength following resistance exercise. Am J Physiol Regul Integr Comp Physiol. 2015;309(4):R389-98.
17. Mawhinney $C$, Jones $H_{\text {, Joo } C H}$, Low DA, Green DJ, Gregson W. Influence of cold-water immersion on limb and cutaneous blood flow after exercise. Med Sci Sports Exerc. 2013;45(12):2277-85.

18. Stanley J, Peake JM, Coombes JS, Buchheit M. Central and peripheral adjustments during high-intensity exercise following cold water immersion. Eur J Appl Physiol. 2014;114(1):147-63.

19. Frohlich M, Faude O, Klein M, Pieter A, Emrich E, Meyer T. Strength training adaptations after cold-water immersion. J Strength Cond Res. 2014;28(9):2628-33.

20. Machado AF, Almeida AC, Micheletti JK, Vanderlei FM, Tribst MF, Netto Junior J, Pastre CM. Dosages of cold-water immersion post exercise on functional and clinical responses: A randomized controlled trial. Scand J Med Sci Sport. 2017;27(11):1356-63.

21. Machado AF, Ferreira PH, Micheletti JK, de Almeida AC, Lemes íR, Vanderlei FM, et al. Can water temperature and immersion time influence the effect of cold water immersion on muscle soreness? A systematic review and meta-analysis. Sports Med. 2016;46(4):503-14.

22. Peake JM, Roberts LA, Figueiredo VC, Egner I, Krog S, Aas SN, et al. The effects of cold water immersion and active recovery on inflammation and cell stress responses in human skeletal muscle after resistance exercise. J Physiol. 2017;595(3):695-711.

23. Vieira A, Siqueira AF, Ferreira-Junior JB, do Carmo J, Durigan JL, Blazevich A, et al. The effect of wate temperature during cold-water immersion on recovery from exercise-induced muscle damage. Int J Sports Med. 2016;37(12):937-43.

24. Leeder J, Gissane C, van Someren K, Gregson W, Howatson G. Cold water immersion and recovery from strenuous exercise: a meta-analysis. Br J Sports Med. 2012;46(4):233-40.

25. Roberts LA, RaastadT, Markworth JF, Figueiredo VC, Egner IM, Shield A, et al. Post-exercise cold water immersion attenuates acute anabolic signalling and long-term adaptations in muscle to strength training. J Physiol. 2015;593(18):4285-301.

26. Ihsan M, Watson G, Abbiss CR. What are the physiological mechanisms for post-exercise cold water immersion in the recovery from prolonged endurance and intermittent exercise? Sports Med. 2016;46(8):1095-109.

27. Allan R, Mawhinney C. Is the ice bath finally melting? CWI is no greater than active recovery upon local and systemic inflammatory cellular stress in humans. J Physiol. 2016;595(6):1857-8.

28. Teixeira AO, Franco OS, Borges MM, Martins CN, Guerreiro LF, da Rosa CE, et al. The importance of adjustments for changes in plasma volume in the interpretation of hematological and inflmmatory responses after resistance exercise. J Exerc Physiol. 2014;17(4):72-83.

29. Bleakley C, McDonough S, Gardner E, Baxter GD, Hopkins JT, Davison GW. Cold-water immersion (cryotherapy) for preventing and treating muscle soreness after exercise. Cochrane Database Syst Rev. 2012;15;(2):CD008262.

30. Flann KL, LaStayo PC, McClain DA, Hazel M, Lindstedt SL. Muscle damage and muscle remodeling: no pain, no gain? J Exp Biol. 2011;214(Pt 4):674-9. 